\title{
TRADISI INTELEKTUAL ISLAM DI INDONESIA ABAD VII-XXI M
}

\author{
Fabian Fadhly \\ Email: fabianfadhly@ymail.com \\ Prodi Magister Sejarah Kebudayaan Islam \\ Universitas Sunan Gunung Djati
}

\begin{abstract}
Abstrak
Tradisi intelektual Islam berkembang melalui tiga periode yaitu zaman klasik, zaman pertengahan dan zaman modern. Ketiga zaman ni memiliki karakteristik dan metode yang berbeda dalam mengembangkan tradisi intelektual Islam, walaupun zaman klasik memliki pengaruh yang kuat mengenai keberkembangan tradisi intelektual Islam pada zaman selanjutnya. Tulisan ini dikedepankan sebagai usaha untuk memberikan pemahaman dan pemaknaan yang tepat, bagaimana Islam menjadi bagian yang tidak terpisah bagi pengembangan intelektualitas kaum muslim yang lebih dikenal dengan tradsisi intelektual Islam (islamic intellectual tradition) dan masih berlangsung sampai saat ini terutama di wilayah Indonesia.Tulisan ini berupaya untuk mencoba untuk menguraikan dan memperlihatkan Islam memiliki peran yang penting dalam membangung tradisi intelektual yanbg dimulai melalui pengajaran di pondok dan/atau pesantren. Metode yang dikedepankan dalam tulisan ini adalah metode deskritif dengan pendekatan analitis. Zaman klasik memberikan sumbangan terhadap pengembangan keintelektualan dengan menempatkan metode yang berkembang dalam pengajaran dan pendidikan yang dipraktekkan mulai zaman Nabi Muhammad saw yaitu metode metode, tulisan, dan hafalan. Zaman Pertengahan memiliki sumbangan terhadap munculnya institusi-institusi yang membantu dan mengembang tradisi intelektual Islam. Zaman Modern merupakan pergulatan tradisi intelektual Islam Indonesia, yang melahirkan dua kelompok kaum muda dan kaum tua. Kaum muda mengedepankan pentingnya pembaharuan pemikiran dalam ranah pemahaman Islam, dengan metode mengembalikan Islam pada tempatnya melalui pemahaman ajaran Islam yang menghilangkan sisi taqlid dan memurnikan ajaran Islam
\end{abstract}

Kata Kunci, Tradisi intelektual Islam, Indonesia

\begin{abstract}
The intellectual tradition of Islam evolved through three periods of classical times, medieval times and modern times. These three ages have different characteristics and methods of developing Islamic intellectual traditions, although the classical period has a strong influence on the development of Islamic intellectual traditions in later ages. This paper is put forward as an attempt to provide a proper understanding and meaning, how Islam is an integral part of the intellectual development of Muslims better known as Islamic intellectual traditions and is still going on today especially in Indonesia. Seeks to describe
\end{abstract}


and demonstrate Islam has an important role in building an intellectual tradition that begins through teaching in cottages and / or boarding schools. The method put forward in this paper is descriptive method with analytical approach. The classical age contributes to the development of intellectuality by placing a growing method of teaching and education practiced from the time of Prophet Muhammad SAW methods of writing, writing and rote. The Middle Ages contributed to the emergence of institutions that helped and expanded the Islamic intellectual tradition. Modern era is a struggle of Indonesian Islamic intellectual tradition, which gave birth to two groups of young people and the elderly. Young people prioritize the importance of renewal of thought in the realm of Islamic understanding, with the method of restoring Islam in its place through the understanding of Islamic teachings that remove the taqlid side and purify the teachings of Islam

Keywords: Islamic Intellectual Tradition Indonesia,

\section{PENDAHULUAN}

Tradisi intelektual Islam muncul sebagai pergerakan yang berkembang dari masa ke masa mulai dari turunnya Islam di jazirah Arab atau lebih tepatnya di Mekkah, berfungsi sebagai sebuah agama yang kembali mengingatkan manusia akan ke-Esa-an Allah Swt. ${ }^{1}$ Islam seperti layaknya agama-agama lain yang memiliki berbagai fase, yaitu fase ke-Tuhanan dan metafisika, fase manusiamanusia agung (Nabi dan para sahabat), dan fase manusia biasa. ${ }^{2}$ Fase-fase ini memberikan pengaruh yang besar terhadaap perkembangan tradisi intelektual Islam yang kemudian membantu membangun berbagai macam daulah atau dinasti yang memperluas kawasan Islam, ${ }^{3}$ tidak hanya berada di wilayah semenanjung Arabia melainkan sampai ke wilayah Andalusia yang dikenal saat ini sebagai Spanyol. ${ }^{4}$

\footnotetext{
${ }^{1}$ QS. Al-Ikhlas (112).

${ }^{2}$ Mun'im Sirry, Tradisi Intelektual Islam Rekonfigurasi Sumber Otoritas Agama, Madani, Malang, 2015, hlm. 4.

${ }^{3}$ Richard C. Martin menyebutkan Islam dibentuk menjadi sebuah kerajaan yang didominasi oleh khalifah bermula dari Khulafa Rasyidun yang dimulai setelah wafatnya Nabi Muhammad tahun 632-661 M, dilanjutkan dengan dinasti Ummayah (661-750 M), dan dinasti Abbasiyah (750-1258 M). Zaman Abbasiyah merupakan munculnya berbagai ilmu yang melatr belakangi berkembang Islam tidak hanya sebagai ajaran yang bersifat peribadatan, melainkan pula sebagai agama yang mengedepankan pengembangan ilmu pengetahuan dengan munculnya, ilmu-ilmu al-Quran, Fiqih dan ilmu mengenai trdisi intelektual yang berkaitan dengan kenabia Nabi Muhammad saw (prophetic tradition studies). (Richard C. Martin, Islam, a cultural perspective), Prentice-Hall, Inc, New Jersey, 1982, pp. 23-24.

${ }^{4}$ Philip K. Hitti lebih lanjut mengungkapkan bahasa Arab sebagai lingua franca Islam mmeberikan perubahan terhadap masyarakat-masayrakat yang disinggahi oleh Islam sebagai agama yang mampu melewati kemapanan tidak hanya muslim sebagai penganutnya tetapi umat Kristiani, Yahudi, Semit, Hamit, dan Indo-Eropa. Keadaan ini mulai berlangsung dari pertengahan abad ke delapan, bahasa Arab menjadi instrumen untuk mengantarkan pemikiran-pemikiran mengenai ilmu pengetahuan, filsafat, dan kesusastraan yang terjadi selama tiga ratus tahun dengan mendominasi dibandingkan dengan bahasa Latin, Hindi, Cina, atau bahasa lain yang digunakan saat itu. (Phikip K. Hitti, Islam A Way Of Life, Regnery/Gateway, Inc. Indiana, 1970, pp. 106.
} 
Tradisi intelelektual Islam berakar pada aqidah (believe), keyakinan ini yang mendorong Islam berubah dalam cara berfikir tidak berupa dalam cara berkeyakinan. Keadaan ini mejadi pembeda dengan agama samawi lain yang mengalami perubahan-perubahan yang terjadi seperti pada agama Protestan abad 16 M, Katolik pada tahun 1960 dengan adanya aggiornamento. Islam tidak mengalami perubahan dalam kerangkan berakidah atau dikenal dengan the framework of ortodoxy and tradition. ${ }^{5}$

Tradisi intelektual islam dibangun dengan tidak hanya berdasarkan kepada keluasan Islam dengan mengedepankan dominasi Arab, melainkan pula berinteraksi dengan kebudayaan dan bangsa lainnya. Persia, Turks, Hindi, menjadi bagian yang tidak terpisahkan dengan Islam tidak hanya sebagai agama yang mengajarkan kesalehan tanpa melalui cara berfikir yang rasional atau dikenal dengan pemahaman keagamaan dengan menggunakan dalil aql dengan berlandaskan kepada al-Quran dan al-Hadits (dalil naql) sebagai rujukan utamanya. $^{6}$

Bangsa melayu bagian lain yang terpengaruh dengan berkembang dan meluasnya wilayah Islam, sebagai sebuah ajaran yang mentradisikan ilmu dan keilmuwan. Wilayah ini dikenal dengan kawasan Asia Tenggara sebagai sebuah dunia kebudayaan melayu yang syarat dengan keunikan-keunikan yang berbeda dengan ketiga kebudayaan dari ketiga bangsa tersebut. Wilayah ini terbentang mulai dari dari Malaysia, Indonesia sampai ke Filipina Selatan (Kepulauan Mindanao). Homogenitas etnis melayu di wilayah ini tidak serta merta mendominasi wilayah tersebut, tanpa melihat etnis lain yang terdapat di wilayah Asia Tenggara, realitas keberagaman (heterogen) ini muncul dari sebuah kenyataan sosial dan budaya yang berkembang dari penduduk yang mendiami Asia Tenggara, Wilayah ini merupakan kawasan kebudayaan yang berdasarkan etnolingusitik sangat luas dan beragam. Islam dalam kawasan Melayu ini mempunyai perjalan panjang terhadap proses Islamisasi berbagai etnis baik etnis Melayu maupun etnis lain yang berdiam diri di wilayah Asia Tenggara. ${ }^{7}$

\footnotetext{
${ }^{5}$ Syyed Hosein Nasr, Islam Religion, History, and Civiulization, HarperSanFransisco, New York, 2003, pp. 173 and 174.

${ }^{6}$ S. I. Poeradisastra memberikan penjelasan bagaimana tradisi intelektual Islam berkembang mulai dari zaman Nabi Muhammad saw dengan memberikan anjuran untuk belajar membaca dan menulis, sampai kepada Islam berkembang sebagai sebuah peradaban yang jauh melampaui wilayah-wilayah peradaban yang telah mapan pada saaat itu yaitu imperium Rumawi. Tradisi keilmuan ini terus dikembangkan oleh dinasti Ummayyah di Damsakus (660-750 M) dan mencapai puncak pada dinasti Abbasiyah (750-1258). Puncak kejayaan keilmuan Islam digambarkan dengan munculnya lembaga Dar al-Hikmah sebuah perpustakaan, pusat penerjermahan, observatorium bintang yang diprakarsai oleh Khalifah al-Ma'mun ibn Harun arRasyid pada tahun 1230. (S. I. Poeradisastra, Sumbangan Islam Kepada Ilmu Dan Kebudayaan Modern, Girimukti Pasaka, Jakarta, 1981, hlm. 8-10).

7 Ajid Tohir, Studi Kawasan Dunia Isalm Perspektif Etno-Linguistik dan Geo-Politik, Rajawali Press, Jakarta, 2011, hlm. 323. Perkembangan masyarakat Islam di Asia Tenggara yang tergolong kelompok masyarakat minoritas di suatu negara tertentu terdapat di Vietnam, Kamboja, Burma, Thailand, Singapura dan Filipina. Meskipun masyarakat Islam termasuk kelompok masyarakat minoritas di sejumlah negara di kawasan Asia Tenggara yang disebutkan ini, namun ada juga tempat atau daerah tertentu yang merupakan wilayah dari suatu negara tersebut mempunyai penduduk yang mayoritas beragama Islam, misalnya di Pulau Mindanao dan Kepulauan Sulu di
} 
Indonesia sebagai salah satu bagian dari kebudayaan melayu secara keseluruhan yang berada di wilayah Asia Tenggara, menjadi salah satu daerah yang dipengaruhi oleh tradisi intelektual Islam yang berkembang mulai dari abad ke-7 M yang digambarkan Sir Thomas Arnold bahwa "tradisi ini masuk dengan pengaruh dari para pedagang yang berasal dari Semenanjung Arab pada pertama dari Hijrah Nabi. ${ }^{8}$

Intelektualitas kaum muslim/Islam yang dimulai abad $7 \mathrm{M}$, diperkenalkan melalui kegiatan-kegiatan keagamaan yang dilakukan oleh pedagang Persia, Gujarat (India) dan Arabia yang dilakukan di tempat para pedagang ini tinggal. Tempat tinggal para pedagang yang memiliki fungsi ganda sebagi guru agama (religious teachers), mengajarkan Islam sebagai sebuah ajaran yang mendekatkan pemeluknya kepada ilmu pengetahuan di tempat yang dikenal pada saat ini sebagai "Pondok" yang memiliki fungsi "to get religious advice."

Pondok yang memiliki fungsi "to get religious advice" berubah menjadi sebuah institusi pendidikan tradisional yang disebut "pesantren" yang mulai mengajarkan pendalaman ajaran Islam di Indonesia, meskipun pesantren dalam arti lembaga pendidikan tempat dilakukannya pengajaran tekstual baru muncul pada sekitar abad ke-18, namun berdasarkan catatan sejarah disebutkan bahwa berdirinya pesantren sesungguhnya sudah ada sejak masa-masa awal penyebaran Islam di Indonesia, terutama di Jawa. Tokoh yang pertama kali mendirikan pesantren adalah Maulana Malik Ibrahim (wafat 1419 M), tokoh Walisongo. Maulana Malik Ibrahim menggunakan masjid dan pesantren untuk pengajaran ilmu-ilmu agama Islam, yang pada gilirannya melahirkan tokoh-tokoh Walisongo yang juga mendirikan pesantren di wilayahnya masing-masing, seperti Sunan

Filipina Selatan.3 Masyarakat Islam di wilayah ini disebut Moro. Jumlah mereka sekitar 4,5 juta jiwa atau $9 \%$ dari seluruh penduduk Filipina. Di Singapura masyarakat Islam berjumlah $16 \%$ dari seluruh penduduk-nya, di Burma 3,9 \% dan di Muangthai sekitar $4 \%$. Sementara itu, di negaranegara yang terkenal memiliki penduduk mayoritas masyarakat Islam, seperti di Indonesia telah diperoleh keterangan bahwa saat ini $90 \%$ penduduknya beragama Islam, di Malaysia ada $55 \%$ yang beragama Islam dari seluruh jumlah penduduknya, dan di Brunei Darussalam sekalipun tidak diketahui secara pasti berapa persen jumlah penduduknya yang beragama Islam, tetapi negara ini terkenal mempunyai penduduk yang sebagian besar beragama Islam dari jumlah penduduknya yang berkisar 200.000 jiwa. (M. Dahlan M., Dinamika Perkembangan Islam Di Asia Tenggara Perspektif Histori, Jurnal Adabiyah Vol. XIII nomor 1/2013, hlm. 115.)

${ }^{8}$ Sir Thomas Arnold meletakan Islam berada di wilayah Indonesia bersamaan dengan abad pertama Hijrah atau abad tujuh Masehi, dilandasi oleh pandangan bahwa bangsa Arab merupakan pelaku perniagaan yang acap kali melakukan perniagaannya dengan melewati berbagai wilayah dan tindakan ini dilakukan sejak masa permulaan sekali. Lihat: Hamka, Sejarah Umat Islam IV, Bulan Bintang, Jakarta, 1976, hlm. 35-36.

${ }^{9}$ Rusydy Zakaria, Overview Of Indonesian Islamic Education A Social, Historical and Political persepective, A thesis Submitted in partial fulfillment of The requirement for the degree of Master of Philosophy at The School of Education The University of Waikato, 2007, pp. 2. Tradisi intelektual Islam Abad ke-7 M di Indonesia layaknya Semenanjung Arabia pada saat itu, yang lebih mengedepankan kemurnian akan ajaran Islam itu sendiri, atau Islam sebagaimana adanya sesuai dengan penyampaian Islam melalui lisan Nabi Muhammad saw berdasarkan tuntunan Allah swt yang termaktub dalam al-Quran al-Hadits. 
Ampel di Surabaya, Sunan Giri di Gresik, Sunan Bonang di Tuban, Sunan Drajat di Lamongan, dan Raden Fatah di Demak. ${ }^{10}$

Ajaran Islam yang membawa kepada perubahan intelektuallitas melayu Indomesia dengan pengaruh nilai-nilai Islam dalam pemikiran politik atau ketatanegaraan telah dipraktikkan oleh kerajaan Islam seperti tercermin pada tiga nilai universal yakni 'adil, syara', dan musyawarah. 'Adil, misalnya sudah ditulis dalam mata uang Aceh pada abad ke-13. Pepatah "raja adil raja disembah, raja lalim raja disanggah" menunjukkan kuatnya konsep adil. Syara' menggantikan kekuasaan mutlak perorangan raja. Ada suatu sistem yang disebut syara' yang harus ditaati bersama. Minangkabau memiliki ungkapan yang menunjukkan budaya melayu, "Adat basandi syara', syara' basandi kitabullah". Kemudian musyawarah juga menjadi praktik di kerajaan-kerajaan Islam di luar Jawa. ${ }^{11}$

Kolonialisasi Barat (Eropa) terhadap Indonesia memberikan pengaruh yang cukup besar terhadap perubahan tradisi intelektual kaum muslim. Keadaan ini terlihat melalui runtuhnnya Kekaisaran Turki Utsmani yang menyebabkan seluruh wilayah muslim (Muslim World) didominasi Inggris, Perancis, Spanyol, Belanda dan lainnya. Belanda menguasai Indonesia selama kurang lebih tiga ratus lima puluh tahun, dengan menggunakan kekuatan represif (iron claws) untuk menekan sekolah-sekolah swasta ${ }^{12}$ yang ditujukkan untuk membentuk kader-kader dalam melawan pemerintah kolonial. ${ }^{13}$

Perkembangan tradisi intelektual Indonesia terutama berkaitan dengan kemampuan umat Islam, menguat dengan kemerdekaan Indonesia. Penguatan ini terjadi pada pertengahan tahun 1950, yang dipengaruhi oleh munculnya tokoh pemikir seperti Agus Salim, Hassan Bandung, Muhammad Natsir dan Hamka. Kedua tokoh terakhir merupakan nagian dari MASYUMI (Masyarakat Syura Muslimin Indonesia) yang memiliki peran penting dalam meletakan gagasangagasan pemikiran Islam di Indonesia. pengaruh dari keduanya tidak hanya merubahan traidis intelektual Islam di Indonesia, melainkan pula membantu

\footnotetext{
${ }^{10}$ Mohamad Kholil, Menggagas Pesantren sebagai Pusat Peradaban Muslim di Indonesia, Media Akademika, Vol. 26, No. 3, Juli 2011, hlm. 298-299. Dalam konteks saat ini, pembahasan seputar eksistensi pesantren dalam kerangka pendidikan Islam di Indonesia merupakan sesuatu yang dirasa makin penting. Dengan diterbitkannya Undang- Undang Sisdiknas No. 20 Tahun 2003 dan Peraturan Pemerintah No. 55 Tahun 2007 tentang Pendidikan Agama dan Keagamaan, pesantren seperti mendapatkan "amunisi" baru yang memposisikannya secara formal setara dengan modelmodel pendidikan yang lain (pendidikan formal) di hadapan Undang- Undang dan Kebijakan Pemerintah. Kondisi ini tentunya sangat positif sekaligus merupakan sebuah tantangan tersendiri bagi eksistensi dan masa depan pesantren.

${ }^{11}$ Mastuki HS, Islam, Budaya Indonesia, Dan Posisi Kajian Islam Di Perguruan Tinggi Islam, Khazanah: Vol. XII. No. 01 Januari-Juni 2014, hlm. 18.

${ }^{12}$ Sekolah-sekolah swasta pada masa pemerintahan kolonial Belanda merupaklan sekolah-sekolah yang didirikan oleh pengajar Islam yang dikenal dengan pondok dan/atau pesantren, madrasah dengan karakteristik yang sama dengan awal Islam masuk ke Indonesia atau bersifat tradisional, atau berbeda penamaan seperti Surau di Sumatera Barat, Dayah atau Meusah di Aceh. Lihat Rusydy Zakaria, Overview Of Indonesian Islamic Education A Social, Historical and Political persepective, A thesis Submitted in partial fulfillment of The requirement for the degree of Master of Philosophy at The School of Education The University of Waikato, 2007, pp. 2.

${ }^{13}$ Che Noraini Hashim \& Hasan Langgulung, Islamic Religious Curriculum in Muslim Countries: The Experiences of Indonesia and Malaysia, Bulletin of Education \& Research June 2008, Vol. 30, No. 1, pp. 5.
} 
Malaysia melalui hubungan yang dibangun dalam ranah organisasi ke-Islaman dalam membangun dan mengembangkan intelektualitas muslim Malaysia. Peran yang dilakukan oleh Muhammad Natsir dan Hamka ditunjukkan dengan berkembangnya tulisan-tulisan kedua tokoh MASYUMI ini di Malaysia pada awal tahun $1960 .^{14}$

Tulisan ini dikedepankan sebagai usaha untuk memberikan pemahaman dan pemaknaan yang tepat, bagaimana Islam menjadi bagian yang tidak terpisah bagi pengembangan intelektualitas kaum muslim yang lebih dikenal dengan tradsisi intelektual Islam (islamic intellectual tradition) dan masih berlangsung sampai saat ini terutama di wilayah Indonesia. Tulisan ini berupaya untuk mencoba untuk menguraikan dan memperlihatkan Islam memiliki peran yang penting dalam membangung tradisi intelektual yanbg dimulai melalui pengajaran di pondok dan/atau pesantren. Metode yang dikedepankan dalam tulisan ini adalah metode deskritif dengan pendekatan analitis. Deskriptif digunakan untuk menunjukkan gambaran Islam yang mendominasi pemikiran masyarakat Indonesia mulai dari masuknya Islam ke Indonesia pada zaman klasik sampai dengan zaman modern. Pendekatan analitis ditujukan untuk mengurai lebih dalam mengenai esensi yang terkandung dalam perjalanan tradisi intelektual Islam dari permulaan Islma di Indonesia.

\section{PEMBAHASAN}

\section{Alur Perkembangan Tradisi Intelektual Islam Indonesia Klasik}

Tradisi Intelektual Islam di Indonesia bermula dari Islam sebagai agama yang berinteraksi antara pedagang-pedagang yang berasal dari semenanjung Arabia dengan warga pribumi Indonesia. interaksi-interaksi yang muncul tersebut mengarahkan perlunya pengembangan intelektualitas masyarakat Islam Indonesia, yang berbeda secara soaial, budaya, dan ekonomi. Keadaan-keadaan yang berbeda ini menuntuk tradisi intelektual dibangun berdasarkan keselarasan kearifan yang dimiliki oleh Indonesiaa dengan ajaran-ajaran Islam, ijtihad menjadi titik penting dari munculnya dan berkembangnya tradisi intelektual isalm yang dilegitimasi oleh makna ijtihad yang mengakar secara mendalam pada Islam. ${ }^{15}$ Alur

\footnotetext{
${ }^{14}$ Norazlan Hadi Yaacob, Muslim Intellectuals and the Idea of Madani (Civil) Society Formation in Indonesia and Malaysia, 1990s-2000s, Journal of Applied Sciences Research, 9(6): 2013, pp. 3469. Norazlan Hadi Yaacob mengungkapkan kemunculan kembali tradisi inteltual Islam pada tahun 1960 di Malaysia di wujudkan dengan bermunculannya seminar-seminar, penerbitan bukubuku yang menunjukkan berbagai segi dalam Islam yang patut diperdebatkan. Organisasi yang memiliki peran penting saat itu, merupakan organisasi yang dipimpin oleh Anwar Ibrahim yang dinamai Angkatan Belia Islam (ABIM) yang mendapatkan tanggapan postif dari para ilmuwan muslim, yang tidak hanya memberikan dampak terhadap pengembangan keilmuan kaum muslim Malaysia melainkan pula terhadap pengembangan paham intelektual Islam (Islamic intellectualism) pada masayrakat Malaysia.

${ }^{15}$ Ijtihad merupakan proses dari upaya untuk memecahkan permasalahan yang tidak dinyatakan secara implisit di dalam al-Quran dan al-Hadits. Ijtihad dan langkah-langkah yang terdapat di dalamnya tidak dapat dipisahkan dari pengaruh politik dan sosial yang dimiliki oleh mujtahid dalam melaksanakn ijtihad tersebut. Keadaan ini dapat dilihat bagaimana perpotlitikan dan keadaan sosial mempengaruhi al-Farabi, al-Kindi, al-Khawarizmi, Ibnu Rushd, Ibnu Sina dan alGhazali dalam mengambil keputusan yang berkaitan dengan ajaran Islam yang berkembang di wilayah tempat para inteleltual muslim ini lahir tumbuh dan berkembang. Pengaruh politik dan
} 
intelektualitas Islam di Indonesia bermula dan berkembang di Aceh yang dapat dilihat dari ajaran Islam yang mempengaruhi adat-istiadat Aceh. Pengaruh ini dibuktikan dengan pepatah yang berbunyi: Hukom ngo Adat lagee Zat ngo Sipheuet (hukum dengan adat seperti benda dengan sifatnya, tidak terpisah). Hukum di sini diartikan dengan hukum Islam yang diajarkan oleh para ulama. ${ }^{16}$

Pedagang-pedagang muslim dari Arab, Persia, dan India pada Abad ke-7 M telah melakukan aktifitas ekonomi berdagang dengan masyarakat asli Indonesia jauh sebelum ditakluknya Malaka oleh Portugis pada tahun 1511 M. Malaka pada saat itu merupakan pusat utama lalu lintas perdagangan dan pelayaran yang membawa hasil hutan dan rempah-rempah dari seluruh Nusantara ke Cina dan India, keadaan ini menempatkan Malaka pada saat itu sebagi mata rantai pelayaran yang penting dalam penyebaran Islam di Indonesia. ${ }^{17}$

Mata rantai penyebaran Islam dari Semenanjung Arabia ke Indonesia beriringan dengan perkembangan lembaga pendidikan pada awal Islam terdiri dari dua tingkat: Tingkat pertama, yaitu maktab/Kuttab dan masjid, yaitu lembaga pendidikan terendah, tempat anak-anak mengenal dasar-dasar baca, tulis dan hitung, dan tempat para remaja belajar dasar-dasar ilmu agama, seperti tafsir, hadits, fiqh dan bahasa. Tingkat kedua, yaitu pendalaman, di mana para pelajar yang ingin memperdalam ilmunya, pergi ke luar daerah menuntut ilmu kepada para ahli dalam bidangnya masing-masing, umumnya ilmu agama. Pengajarannya berlangsung di masjid-masjid atau di rumah-rumah ulama bersangkutan atau di istana bagi anak-anak penguasa dengan memanggil ulama ahlinya ke istana. ${ }^{18}$

Dua tingkatan sisntem pendidikan ini mendapatkan pengaruh yang cukup besar dari Metode pengajaran Islam yang pernah dipraktekkan pada masa pemerintahan Dinasti Abasyiah dapat dikelompokkan dalam tiga kategori yaitu metode lisan, tulisan, dan hafalan. Metode lisan berupa dikte, ceramah, qira'ah, dan diskusi. Metode imlak adalah metode yang dipakai dalam setiap tingkatan institusi pendidikan Islam klasik. Metode imlak berfungsi untuk menyampaikan pengetahuan yang dianggap baik dan aman karena anak didik mempunyai catatan, hal ini juga untuk membantu daya ingat anak yang kuat. Metode diskusi

sosial terjadi pula pada Mulla Sadra dan Murtadha Mutahari pada masa Islam modern (contemprary Islam era). (Raihani, Religious Intellectualism And Society, An Editorial Note, APJRS, Vol. 1, No. 1, March 2015, pp. 2).

${ }^{16}$ Ismuha, Islam Dan Masyarakat Aceh dalam Agama dan Perubahan Sosial, Rajawali, 1983. hlm. 5. Poteu Meureuhom diartikan sebagai Sultan Iskandar Muda yang memiliki kedudukan sebagai pemimpin dan ulama dikarenakan kemampuannya dalam memimpin dan menguasai ilmu-ilmu islam (pen.)

${ }^{17}$ Badri Yatim, Sejarah Peradaban Islam (Dirasah Islamiyah II), Rajawali Pers, Jakarta, 2011, hlm. 191-192. Hukum Islam pada era ini mulai mewarnai kehidupan bangsa Indonesia, dengan fiqih yang berasal dari jazirah Arab dalam menentukan segala tindakan umat Islam. Fiqih walaupun telah diakui sebagai lembaga yang mengatur kehidupan masyarakat pada saat itu tidak menjadikannya sebagai kekuatan utama dalam pergaulan antar masyarakat. Tasawuf dan amalan tarekat yang menjadi kegiatan utama dalam pergaulan, pemimpin-pemimpin atau para guru suluk (sjujuch al-turuq) yang mendapatkan pernghormatan dibandingkan ahli-ahli ilmu kalam (mutakallimun), maupun para ahli hukum (fuqaha). A. Mukti Ali, Alam Pikiran Islam Modern Di Indonesia dan Modern Islamic Thaought In Indonesia, Jajasan Nida, Jogjakarta, 1969, hlm. 5.

18 Mugiyono, Perkembangan Pemikiran Dan Peradaban Islam Dalam Perspektif Sejarah, JIA/Juni 2013/Th.XIV/Nomor 1/1-20, hlm. 11. 
merupakan metode khas dalam pendidikan Islam klasik. Ulama-ulama sering mengadakan majlis-majlis diskusi. Metode ini banyak digunakan dalam pengajaran ilmu-ilmu filsafat dan fiqih. Metode diskusi bertujuan melatih siswa mengamalkan ilmu dan menggunakan daya berfikir secara aktif, metode yang paling mudah untuk memperoleh penguasaan ilmu pengetahuan melalui latihan lisan guna mengungkap pikiran-pikiran dengan jelas dalam diskusi ilmiah. ${ }^{19}$

Alur perkembangan tradisi intelektual Islam di Indonesia berkembang pada abad ke $7 \mathrm{M}$, tidak dapat dikatakan sepenuhnya benar, proses islamisasi secara massal - yang ditandai oleh munculnya berbagai institusi Islam di Nusantara nampaknya baru menemukan akselerasinya pada pasca abad ke-12 hingga ke-16 Masehi. Jika memang demikian, maka benarlah apa yang ditegaskan oleh Harun Nasution sebagaimana dikemukakan Muzani bahwa Islam yang datang dan berkembang di Indonesia bukanlah Islam zaman keemasan dengan pemikiran rasional dan kebudayaannya yang tinggi, melainkan Islam yang sudah berada pada titik kemunduran dengan pemikiran tradisional dan corak tarekat dan fikihnya. Kenyataan sejarah semacam ini, kemudian sangat mempengaruhi corak pemikiran Islam yang berkembang di Indonesia, dan sekaligus berimplikasi terhadap upaya pelacakan khasanah intelektualitasnya. ${ }^{20}$

Syed Muhammad Naquib al-Attas memberikan pandangan bahwa selain akulturasi yang dilakukan pada tahun 1200-1400 M dalam bidang fiqih sebagai fase pertama, dan berkembangnya teologi Islam serta tasawwuf pada tahun 1400$1700 \mathrm{M}$ sebagai fase kedua, terdapat fase ketiga yang mengambarkan terjadinya penguatan terhadap kedua fase tersebut ditunjukkan dengan pengaruh keduanya. Pengaruh ini dalam melakukan revolusi terhadap pandangan atau paradigmaparadigma muslim Melayu, yang berawal mengedepankan fenomena mitologimitologi yang berkembang dimasyarakat, berubah menjadi padangan yang bersifat etnisional dengan mengedepankan kemampuan nalar masyarakat di Melayu. $^{21}$

Era klasik sperti halnya di wilayah Semenanjung Arabia beserta wialayah taklukan Islam, Indonesia yang dikenal pada saat itu sebagai Nusantara memunculkan tokoh-tokoh ulama intelektual terkenal semacam Hamzah Fansuri, Syamsudin Pasai (W. 1040/1630), Nuruddin Al Raniri (W.1068/1658), dan Abdurauf al-Singkili (1024-1105 H). Tokoh-tokoh ini mempunyai jaringan keilmuan yang luas, baik di dalam maupun luar negeri, sehingga menunjang pengembangan Islam dan gagasan-gagasan mereka sendiri. ${ }^{22}$

Era klasik memiliki peran penting sebagai dasar peletak Indonesia menjadi bagian dari kejayaan Islam dalam tradisi intelektual yang digambarkan melalui

\footnotetext{
${ }^{19}$ Anonim.

${ }^{20}$ Rusdin, Islam Dan Sastra Melayu Klasik, Jurnal Hunafa Vol. 2 No. 3 Desember 2005, hlm. 278 ..

21 Syed Muhammad Naquib al-Attas, Preliminary Statement On A General Theory Of The Islamization Of The Malay-Indonesian Archipelago, Kuala Lumpur, (1969), 29-30. Lihat juga: Syed Hamid bin Syed Jaafar Albar, The Role of Islamic Civilisation in Strengthening the Foreign Relations between Countries of ASEAN, Proceedings ASEAN Community Conference 2015, Bangi, Malaysia, 11-12 November 2015, pp. 12.

22 Azyumardi Azra, Jaringan Ulama Timur Tengah dan Kepulauan Nusantara Abad XVII dan XVIII, Mizan, Bandung,1994.
} 
tokoh-tok kesusaatraan yang menghiasi wilayah kebudayaan Melayu, walaupun di sisi lain muncul pandangan Islam di Indonesia berkembang pada saat Islam mengalami kemunduran dan keruntuhan. Pandangan-pandangan ini menunjukkan Islam memiliki daya tarik mulai dari muncul sampai runtuhnya Islam sebagai kebudayaan yang memunculkan peradaban baru di dunia yang didominasi oleh Dunia Timur (Persia) dan Dunia Barat (Romawi) pad saat itu.

\section{Alur Perkembangan Tradisi Intelektual Islam Indonesia Pertengahan}

Perkembangan wilayah Islam yang dimulai pada masa Khulafa ar-Rayidin, membawa Islam kepada masa kejayaan, tidak hanya mengenai jumlah pemeluk agama rahmatan li al- 'alamin ini melainkan pula perkembangan pemikiran yang ditandai dengan berkembangnya majelis-mejelis ilmu pada masa Dinasti Abbasiyah yang dikenal sebagai peletak dasar munculnya berbagai macam cabang ilmu maupun aliran-aliran keagamaan yang dipekuat pada masa ini. Periode pertengahan merupakan waktu atau zaman Islam menjadi peradaban yang menyatukan berbagai kebudayaan, terutama kebudayaan Arab dan Persia.

Pada masa pertengahan atau Islam klasik ditemukan beragam kelompok atau mazhab, seperti kelompok Islam aliran kalam (Khawarij, Maturidyah, Mu'tazilah, Asyariyah, Qadiriyah, Jabariyah, Syiah, dan Sunni). Mazhab Fiqh (Maliki, Hambali, Hanafi, dan Syafi'i). Dalam bidang filsafat, Islam pernah memiliki tokoh-tokoh yang begitu brilian dalam melahirkan ide-ide filosofisnya, di antaranya, pertama, aliran Peripatetik. Kedua, aliran iluminasionis (Isyraqiyyah). Ketiga, aliran teosofi transenden atau al-Hikmah al-Muta'aliyyah (979-1050/1571-16o0). ${ }^{23}$

Tradisi pemikiran hukum Islam pada masa keemasannya memberikan gambaran yang mengagumkan, di mana pendapat seorang ulama atau cendekiawan tentang suatu masalah dibangun di atas paradigma, kerangka berpikir, atau pun framework tertentu, yang seluruhnya bermuara pada Islamic world view (pandangan hidup Islam). Hal ini menunjukkan bahwa Islam sangat menghargai ijtihād sebagai sebuah proses berpikir yang melahirkan sebuah gagasan besar dalam lapangan ilmu pengetahuan. ${ }^{24}$

\footnotetext{
${ }^{23}$ Fahrurrozi, Ekspresi Keberagamaan Masyarakat Islam Indonesia:Mozaik Multikulturalisme Indonesia, TOLERANSI: Media Komunikasi Umat Bergama, Vol.7, No.1 Januari-Juni 2015, hlm. 19 dan 20. Aliran tarekat tidak hanya menjadi bagian dari proses Islamisasi atau ajaran Islam yang memasuki Asia Tenggara dengan dominasi atau hanya berkaitan dengan Indonesia dan Malaysia yang memiliki peran besar terutama dengan etnis Melayu di dalamnya, melainkan wilayah Brunei Darussalam, Singapura, Filipina, dan Thailand, Myanmar serta etnis Indo-Cina yang mendiami wilayah Laos, Kamboja dan Vietnam. Aspek Teologi menjadi bagian lain dari Islam Asia Tenggara. Aspek Fiqih mulai berkembang pada periode 1200-1400 Masehi, sedangkan bidang teologi mulai muncul dan berkembang pada periode 1400-1700 M. Perkembangan yang pesat Islam di Asia Tenggara pada Abad 13-18 Masehi, tidak menafikan perjalanan Islam sebagai sebuah ajaran agama bermulai dari abad $7 \mathrm{M}$ yang disebarkan jalur perniagaan oleh para pedagang Arab. (Lihat; Asep Achmad Hidayat, Studi Kawasan Muslim Minoritas Asia Tenggara, Pustaka Rahmat, 2014, Bandung, hlm. 18.).

${ }^{24}$ Muhammad Harfin Zuhdi, Tipologi Pemikiran Hukum Islam: Pergulatan Pemikiran Dari Tradisionalis Hingga Liberalis, Ulumuna Jurnal Studi Keislaman, Volume 16 Nomor 1 (Juni) 2012, hlm. 43. Dari rangkaian peristiwa sejarah tersebut, sudah seharusnya menginspirasi untuk menumbuhkan keinginan sebagian pemikir dan cendekiawan muslim untuk kembali
} 
Ketika proses Islamisasi di Indonesia, dunia Islam mulai melemah dan dipengaruhi tasawuf. Andaikan proses islamisasi di Indonesia ini terjadi saat Islam mencapai puncak kejayaannya sebagai super power maka karakter umat Islam di Indonesia lebih optimis dan progresif. ${ }^{25}$ Keadaan ini tidak menyebabkan Islam di Indonesia mengalami keruntuhan inteletual yang dibangun berdasarkan tradisi intelektual Islam pada masa Islam mendominasi cara-cara berfikir keilmuan yang berasal dari nalar dan logika pada ulama intelektual dari bangsa Arab dan bangsa Persia.

Keruntuhan ini pula tidak serta merta menghilangkan ulama intelektual menjadi bagian yang tidak terpisahkan dengan perkembangan ranah-ranah keilmuan, yang terdapat di Indonesia. Sebagaimana diungkapkan oleh Osman Bakar berpandangan Islam muncul di wilayah Asia Tenggara bermula dari munculnya negara muslim pada tahun $1292 \mathrm{M}$ di Sumatera yang dipengaruhi oleh pandangan-pandangan ajaran Islam melalui pemahaman dan penafsiran yang disampaikan oleh Abu Hamid al-Ghzazali. ${ }^{26}$

Islamisasi di Nusantara menggunakan pendekatan kultural sehingga mencitrakan cara-cara yang damai, sedangkan islamisasi di kawasan Timur Tengah menggunakan pendekatan militer berupa penaklukan sehingga mencitrakan kekerasan. Sementara itu, posisi kawasan Nusantara ini terkait dengan waktu proses Islamisasi. Fauzan Saleh menilai bahwa lantaran posisi geografis yang jauh dari pusat penyebaran Islam itu, Indonesia terlambat dalam mengikuti proses islamisasi. ${ }^{27}$ Perlambatan yang terjadi dalam tradisi intelektual Islam yang tidak terlihat pada zaman pertengahan di Indonesia, dapat dilihat dengan munculnya berbagai mascam karya-karya sastra. Keadaan ini berbanding terbalik dengan pusat peradaban Islam zaman klasik yang dipelopori oleh keruntuhan Baghdad pada tahun 1258 oleh Hulagu Khan. ${ }^{28}$ Faktor-faktor yang menyebabkan perbedaan ini coba diungkapkan oleh Syarif: ${ }^{29}$

1) telah banyaknya Filsafat Islam (yang bercorak sufistis) yang dimasukkan al-Ghazali di Timur, demikian pula Ibnu Rusyd dalam memasukkan filsafat Islamnya (yang bercorak rasionalistis) ke dunia Islam di Barat yang akhirnya keduanya bermuara ke arah bidang

\footnotetext{
menghidupkan ruh "pembaruan" Islam, karena merupakan realitas sejarah yang tidak bisa dipungkiri. Perjuangan dalam rangka mewujudkan "pembaruan" seharusnya tetap berpegang pada "rambu-rambu" yang telah disepakati agar tidak keluar dari koridor yang ada. Hal ini penting untuk diperhatikan, karena jika tidak, akan lahir ide, gagasan, atau produk pemikiran yang tidak sejalan dengan semangat al-Qur an dan al-Sunnah.

${ }^{25}$ Mujamil Qomar, Ragam Identitas Islam Di Indonesia Dari Perspektif Kawasan, Epistemé, Vol. 10, No. 2, Desember 2015, hlm. 324

26 Abu Hamid al-Ghzazali di wilayah Asia Tenggar lebih dikenal dengan Imam al-Ghazali penyusun kitab Ihya al- 'Ulum ad-Din.

${ }_{27}$ Fauzan Saleh, Education and the Advancement of Cultural Islam: Rebuilding a "Creater Tradition" for Indonesian Islam”, dalam Alef Theria Wasim et.al, Religious Harmony: Problems, Practice and Education, Oais, Yogyakarta:, 2005, pp. 57.

28 Lihat: Tsuroya Kiswati, Rekonstruksi Metodologis Wacana "Keadilan Gender" Dalam Prespektif Intelektual Muslim Kontemporer, Chapter Seven The Legacy of Islamic Thought: Contribution for the Future, Annual International Confrence On Islamic Studies, hlm. 2035.

${ }^{29}$ M.M, Syarif, Muslim Thought (trans. M. Fachruddin) Diponegoro, Bandung, hlm. 161-164.
} 
rohaniah hingga menghilang dalam mega alam tasauf, sedangkan Ibnu Rusyd menuju ke jurang materialisme;

2) Umat Islam terutama para pemerintahnya (khalifah, sultan, amiramir) melalaikan ilmu pengetahuan dan kebudayaan, dan tidak memberi kesempatan bidang-bidang tersebut untuk berkembang.

3) Terjadinya pemberontakan yang dibarengi dengan serangan dari luar, sehingga menimbulkan kehancuran-kehancuran yang mengakibatkan berhentinya kegiatan pengembangan ilmu pengetahuan dan kebudayaan di dunia Islam.

Perlambatan dan keruntuhan Baghdad tidak menghilangkan tradisi belajar yang telah ada pada masa Nabi terus berkembang pada masa-masa sesudahnya, dan sebagaimana tercacat dalam sejarah bahwa puncak kemajuannya tercapai pada masa khalifah Harun al-Rasyid dan al-Makmun yang berpusat di Bagdad, dan pada masa kejayaan 'Usmaniyah di Spanyol dan Cordova yang berlangsung sekitar delapan abad [711-1492 M]. kemudian sistem pendidikan Islam itu diperluas dengan sistem madrasah yang men-capai puncaknya pada Madrasah Nidzamiyah yang didirikan di Bagdad oleh Nizam al-Mulk. ${ }^{30}$ Kedatangan Islam telah menyebabkan para penyair kita mengembangkan berbagai jenis "baru" seperti ghazal, nizam, dan nalam yang berasal dari Timur Tengah, sedangkan syair berasal dari Arab. Yang kemudian jauh dikembangkan oleh kebudayaan kita ternyata adalah yang disebut terakhir itu sehingga sampai sekarang penulis puisi kita sebut penyair dan bukan, misalnya, puisiwan. ${ }^{31}$

\section{Alur Perkembangan Tradisi Intelektual Islam Indonesia Modern}

Pemikiran Islam kontemporer umumnya ditandai dengan lahirnya suatu kesadaran baru atas keberadaan tradisi di satu sisi dan keberadaan modernitas di sisi yang lain, serta bagaimana sebaiknya membaca keduanya. Maka "tradisi dan modernitas" (al-turâts wa al-hadâtsah) merupakan isu pokok dalam pemikiran Islam kontemporer. Apakah tradisi harus dilihat dengan kacamata modernitas ataukah modernitas harus dilihat dengan kacamata tradisi atau bisakah keduanya dipadukan?. ${ }^{32}$

Muhammad Muslih mengungkapkan pemikiran Islam kontemporer berbeda dengan pemikiran Islam tradisional yang melihat modernitas sebagai semacam dunia lain, dan berbeda pula dengan pemikiran Islam modernis yang menggilas tradisi demi pembaharuan, pemikiran Islam kontemporer melihat bahwa turâts

\footnotetext{
30 Aan Najib, Pembaharuan Pendidikan Islam Konsep Pendidikan Tinggi Islam Menurut Pemikiran Fazlur Rahman, Nadwa | Jurnal Pendidikan Islam Vol. 9, Nomor 2, Oktober 2015, hlm. 114. Pendidikan Islam pada waktu itu telah melahirkan para cendekiawan Muslim yang dikenal hingga ini, maka secara epistemologi Noeng Muhajir sangat argumentatif berkesimpulan bahwa Yunani adalah induk ilmu murni dan Islam adalah induk teknologi.

31 Sapardi Djoko Damono, Kesusastraan Indonesia Sebelum Kemerdekaan, Jurnal Kalam 25 / 2013, hlm. 7. Syair, dalam pengertian terdahulu, merupakan nama jenis seperti halnya puisi. Dalam kaitannya dengan berbagai pembicaraan mengenai puisi di awal perkembangannya, kita menggunakan istilah syair; baru sesudah majalah Pujangga Baru terbit pada 1933 penggunaan kata puisi semakin meluas

32 Mohammad Muslih, Pemikiran Islam Kontemporer, Antara Mode Pemikiran dan Model Pembacaan, Jurnal Tsaqafah, Vol. 8, No. 2, Oktober 2012, hlm. 349.
} 
adalah prestasi sejarah, sementara hadâtsah adalah realitas sejarah. Maka tidak bisa menekan turâts apalagi menafikannya hanya demi pembaharuan; rasionalisasi atau modernisasi sebagaimana perspektif modernis selama ini.Juga tidak bisa menolak begitu saja apa-apa yang datang dari 'perut' hadâtsah, terutama perkembangan sains dan teknologi. Karena sekalipun banyak mengandung kelemahan, karenanya juga dikritik, tetap banyak memberikan penjelasan atas problem kehidupan, keilmuan, mungkin juga keberagamaan. ${ }^{33}$

Pada abad 17-19 M, muncul beberapa tokoh dan gerakan pembaruan di dunia Islam, yang berdasarkan kemunculan dan orientasi gerakannya dapat dibedakan ke dalam tiga episode:

a. Pertama, Shah Waliullah di India, Ahmad bin Abdul Wahhab di Saudi Arabia, dan Muhammad bin Ali al Sanusi di Afrika Utara. Pada masa ini, para tokoh dan gerakan pembaruan mengemuka berkaitan dengan tekanan atau lingkungan internal dan sedikit bersentuhan dengan dampak dari perkembangan peradaban Barat.

b. Kedua, seiring dengan meningkatnya penetrasi koloni Eropa ke dunia Islam, muncul beberapa gerakan jihad (jihadiy movements) pada abad ke-19, sebagai aspek kunci dari pembaruan Islam. Misalnya, sebagai respons terhadap kolonisasi Inggris di anak benua India, para ulama mendeklarasikan, bahwa India tidak bisa lagi disebut dengan "abode of Islam" (dar al Islam), tetapi sebagai "abode of war" (dar al harb).

c. Ketiga, bersamaan dengan kedatangan era modern (abad ke-19 dan seterusnya), tradisi pembaruan keagamaan berlanjut secara lebih intensif dari pada era sebelumnya. Suatu era yang mengumumkan konfrontasi militer dan politik dari kekuatan-kekuatan Barat dengan dunia Islam, dimana masyarakat Muslim mengalami kekalahan (Boyd, 2001: 7-22). Modernisme masyarakat Muslim yang terjadi pada era ini sebagiannya merupakan kelanjutan dari gerakan pembaruan abad 18-19M, dan sebagian yang lain adalah suatu cara untuk menjawab tantangan yang ditunjukkan oleh kemodernan Barat ketika masih tersisa sekepal keyakinan terhadap dasar-dasar keagamaan. $^{34}$

Pembaruan pemikiran Islam yang diintrodusir pada abad 17-19 M. di atas dapat ditemukan pengaruhnya di Indonesia sejak permulaan abad ke-20 melalui kehadiran Muhammadiyah dan Persatuan Islam, yang menjadikan purifikasi atau pemurnian akidah sebagai tema sentral gerakan mereka. Sebagaimana pemikiran pembaruan Ahmad bin Abdul Wahhab dan Muhammad Abduh, episode awal sejarah modernisme Islam Indonesia juga dicirikan oleh semangat untuk keluar dari ikatan-ikatan kaum ortodoks dengan mengedepankan ijtihad dari pada taqlid, menekankan pentingnya qiyas agar dapat merebut semangat hukum yang

\footnotetext{
${ }^{33}$ Ibid.

${ }^{34}$ Anonim
} 
tersimpan dalam tulisan hukum; dan memilih mengurangi ketergantungan pada Hadis demi mendahulukan al Quran dan Sunnah Nabi. ${ }^{35}$

Tradisi intelektual Islam yang megedepankan pemikiran sebagai sebuah upaya untuk mengembalikan Islam sebagai agama yang mencari kebenaran dan menjawab permasalahan yang berbeda antara zaman klasik, pertengahan dan modern, tidak hanya terjadi di berbagai belahan dunia yang dialirin arus Islam sebagai bagian dari masyarakat kawasan tersebut. Indonesia sebagai bagian dari wilayah yang dialiri Islam mengalami perubahan pemikiran yang dikenal dengan upaya pembaharuan keagamaan yang telah muncul dan dipelopori oleh pergerakan ulama antara tahun 1913-1916 di bawah pengaruh pembaharuan pemikiran Syeikh Ahmad Khatib ${ }^{36}$ dan penyebarluasan Paderi yang anti pandangan tradisional dari kalangan ulama saat itu. ${ }^{37}$

Pengaruh Muhammad Abduh terhadap perkembangan tradisi intelektual Islam Indonesia memiliki pengaruh yang cukup besar dan luas. Pengaruh dari Muhammad Abduh yang begitu terlihat melalui sosok Syeikh Ahmad Khatib sebagai ulama pembaharuan yang melahirkan "kaum muda", tidak serta merta menghilangkan pengaruh "kaum tua" yang dikenal dengan tradisionalis. Tradisionalis direpresentasikan oleh Hasyim Asj' ari pelopor berdirinya Nahdathul

Ulama. Ulama intelektual pembaharu di pada abad 19 melalui Djamil Djambek dan Haji Rasul mencoba mendapatkan bentuk baru lembaga pendidikan, bentuk interaksi baru dan bentuk langkah-langkah (gaya) ijtihad yang tetap menghormati Mazhab Syafi'i sebagai acuan. ${ }^{38}$

${ }^{35}$ Greg Barton, Gagasan Islam Liberal di Indonesia: Pemikiran Neo Modernisme Nurcholish Madjid, Djohan Effendi, Ahmad Wahib, dan Abdurrahman Wahid, Paramadina,Jakarta, 1999, hlm. 45.

${ }^{36}$ Achmad Khatib, yang merupakan ulama besar koloni Jâwah yang terakhir di sekitar peralihan abad ke-19/20, bersikap skeptis terhadap meluasnya pengaruh reformisme-modernisme Islam yang terinspirasi oleh pemikiran 'Abduh itu. Meskipun dia sendiri telah terpengaruh oleh reformisme Islam, namun posisinya sebagai penjaga tradisi pengajaran Syafi'iyah membuatnya bersikap kritis terhadap gagasan Abduh mengenai ijtihad dan modernisme. Dia memang menganjurkan muridmuridnya untuk membaca karya-karya 'Abduh, namun dia melakukan ini dengan maksud agar para muridnya menolak ide-ide 'Abduh (Noer 1973: 32). Ternyata, banyak dari muridnya bukan saja membaca, namun juga mengagumi pemikiran-pemikiran 'Abduh. Dengan begitu, Khatib berfungsi sebagai jembatan antara tradisi dan inovasi. Dalam posisi 'perantara' (liminal)67 semacam itu, dia bertindak sebagai bidan bagi kelahiran generasi ulama dan intelektual reformismodernis di masa depan, seperti Mohd. Tahir bin Djalaluddin, M. Djamil Djambek, Abdullah Ahmad, Abdul Karim Amrullah (Hadji Rasul), M. Thaib Umar, Achmad Dachlan, dan Agus Salim serta bagi lahirnya ulama konservatif-tradisionalis di masa depan seperti Syeikh Sulaiman alRasuli dan Hasjim Asj'ari. Lihat Yudi Latif. Inteligensia Muslim dan Kuasa Genealogi Inteligensia Muslim Indonesia Abad Ke-20, Yayasan Abad Demokrasi, Jakarta, 2012, hlm. 129.

${ }^{37}$ Moeflich Hasbullah, Century Of NU-Muhammmoeflich Hasbullah, Adiyah In Indonesia: The Failure Of Islamic Modernism?, Islamika Indonesiana, 1:1 (2014), pp. 23

38 John R. Bowen, Intellectual Pilgrimages and Local Norms in Fashioning Indonesian Islam, REMMM 123, ph. 36. Pada awal sampai pertengahan abad ke-20, Minangkabau terkenal dengan pembaharuannya, termasuk pembaharuan pada madrasah-madrasah yang dahulunya dikenaldengan surau (sama dengan pondok pesantren di jawa dan dayah di Aceh). Ketika itubermunculan madrasah-madrasah (perguruan-perguruan)yang menerapkan sistem modern. Seperti: Perguruan Diniyah Puteri yang dipelopori oleh Zainuddin Labay El-Yunusi dan Rahmah El- Yunnusiah di Padang Panjang, Perguruan Thawalib atau Sumatera Thawalib yang dipelopori oleh Haji Abdul Karim Amrullah (Haji Rasul), ayahnya Hamka, juga di Padang Panjang, Sekolah 
Pada tahun 1897, M. Thaib Umar mulai mendirikan sebuah surau yang dimodernisasi di Batusangkar (Sumatra Barat). Pada tahap ini, 'sistem kelas berjenjang dan pengajaran dalam ruang kelas memang belum diperkenalkan, namun semua teks yang digunakan di sekolah itu merupakan buku-buku cetakan dan kurikulum yang dipakai merupakan kurikulum yang mengadaptasi kurikulum Al-Azhar Kairo. Perlahan tapi pasti, pengaruh mazhab pemikiran 'Abduh menyebar di Hindia Dalam perkembangannya kemudian, sekolah-sekolah yang telah dimodernisasi ini akan disebut sebagai madrasah. ${ }^{39}$

\section{PENUTUP}

Tradisi intelektual Islam Indonesia dibangun bersamaan dengan Islam diturunkan ke dunia melalui lisan Nabi Muhammad saw. Tradisi ini dalam perkembangnya memiliki corak yang berbeda dalam tiap zaman peradaban yang telah berlangsung dalam Islam. Corak yang berbeda itu terjadi mulai zaman klasik, zaman pertengahan dan dan zaman modern. Zaman klasik memberikan sumbangan terhadap pengembangan keintelektualan dengan menempatkan metode yang berkembang dalam pengajaran dan pendidikan yang dipraktekkan mulai zaman Nabi Muhammad saw yaitu metode metode, tulisan, dan hafalan. Metode ini menjadi cara mempengaruhi pengajaran dan pendidikan terhadap kaum muslim pada zaman klasik di Indonesia dengan munculnya pondok dan/atau pesantren sebagai contoh yang nyata dalam membina kaum muslim saat itu.

Zaman Pertengahan memiliki sumbangan terhadap munculnya institusiinstitusi yang membantu dan mengembang tradisi intelektual Islam. Pengembangan ini dibentuk oleh institusi yang dilembagakan melalui aliran-aliran teologi, sufisme, maupun mazhab yang telah jauh berkembang dibandingkan dengan zaman klasik. Keberkembangan ini pun memberikan pengaruh yang cukup besar terhadap tradisi intelektual Islam di Indonesia, dengan dibuktikan menguatnya aliran teologi (ilmu kalam) ahluu sunnah wa al-Jama'ah yang beraliran mazhab Syafi'i, dengan tidak menafikan terdapatnya aliran dan pemikiran Syi'ah yang berkembang bersamaan dengan aliran arus utama Islam di Indonesia pad saat itu.

Zaman Modern merupakan pergulatan tradis intelektual Islam Indonesia, yang melahirkan dua kelompok kaum muda dan kaum tua. Kaum muda mengedepankan pentingnya pembaharuan pemikiran dalam ranah pemahaman

\footnotetext{
Adabiyah oleh Haji Abdullah Ahmad di Padang, Thawalib Parabek di Bukittinggi yang dikenal akrab dengan prakarsa Syaikh Ibrahim Musa Parabek, dan Iain-lain. Tokoh-Tokoh yang mempelopori pendirian sekolah-sekolah modern tersebut rata-rata berpendidikan Timur Tengah yang pada waktu itu juga sedang intens mengadakan pembaharuan. Tokoh-tokoh di atas banyak terinspirasi oleh wacana pembaharuan yang digulirkan oleh Jamaluddin Al-Afghani, uhammad Abduh, dan Rasyid Ridha di Mesir. Sehingga sistem pendidikan yang mereka terapkan di Minangkabau banyak kemiripan dengan sistem pendidikan yang dibangun oleh Muhammad Abduh di Al-Azhar, Mesir. Selanjutnya dapat dilihat Delar Noer, Gerakan Modern, hlm. 38-65. Bandingkan dengan Karel A. Steenbrink, Pesantren Madr sah Sekolah, Pendidikan Islam dalam Kurun Modern, terj. Karel A. Steenbrink dan Abdurrhman, cet. ke-2, (Jakarta: LP3ES, 1994), hlm. 35-65.

${ }^{39}$ Yudi Latif, Inteligensia Muslim dan Kuasa Genealogi Inteligensia Muslim Indonesia Abad Ke20, Yayasan Abad Demokrasi, Jakarta, 2012, hlm. 130.
} 
Islam, dengan metode mengembalikan Islam pada tempatnya melalui pemahaman ajaran Islam yang menghilangkan sisi taqlid dan memurnikan ajaran Islam dari tahayul, khurafat, bid'ah dan kembali kepada ajaran Islam berdasarkan kepada alQuran dan al-Hadits. Gerakan pembaharuan Islam ini dipelopori oleh Syeih Ahmad Khatib yang kemudian melalui pengajaran yang dilakukannya melahirkan tokoh-tokoh seperti Mohd. Tahir bin Djalaluddin, M. Djamil Djambek, Abdullah Ahmad, Abdul Karim Amrullah (Hadji Rasul), M. Thaib Umar, Achmad Dachlan, dan Agus Salim

\section{Daftar Pustaka}

A. Mukti Ali, Alam Pikiran Islam Modern Di Indonesia dan Modern Islamic Thaought In Indonesia, Jajasan Nida, Jogjakarta, 1969.

Aan Najib, Pembaharuan Pendidikan Islam Konsep Pendidikan Tinggi Islam Menurut Pemikiran Fazlur Rahman, Nadwa | Jurnal Pendidikan Islam Vol. 9, Nomor 2, Oktober 2015.

Ajid Tohir, Studi Kawasan Dunia Isalm Perspektif Etno-Linguistik dan GeoPolitik, Rajawali Press, Jakarta, 2011.

Asep Achmad Hidayat, Studi Kawasan Muslim Minoritas Asia Tenggara, Pustaka Rahmat, Bandung, 2014.

Azyumardi Azra, Jaringan Ulama Timur Tengah dan Kepulauan Nusantara Abad XVII dan XVIII, Mizan, Bandung,1994.

Badri Yatim, Sejarah Peradaban Islam (Dirasah Islamiyah II), Rajawali Pers, Jakarta, 2011.

Che Noraini Hashim \& Hasan Langgulung, Islamic Religious Curriculum in Muslim Countries: The Experiences of Indonesia and Malaysia, Bulletin of Education \& Research June 2008, Vol. 30, No. 1.

Fahrurrozi, Ekspresi Keberagamaan Masyarakat Islam Indonesia:Mozaik Multikulturalisme Indonesia, Toleransi: Media Komunikasi Umat Bergama, Vol.7, No.1 Januari-Juni 2015.

Fauzan Saleh, Education and the Advancement of Cultural Islam: Rebuilding a "Creater Tradition" for Indonesian Islam", dalam Alef Theria Wasim et.al, Religious Harmony: Problems, Practice and Education, Oais, Yogyakarta:, 2005.

Greg Barton, Gagasan Islam Liberal di Indonesia: Pemikiran Neo Modernisme Nurcholish Madjid, Djohan Effendi, Ahmad Wahib, dan Abdurrahman Wahid, Paramadina,Jakarta, 1999.

HAMKA, Sejarah Umat Islam IV, Bulan Bintang, Jakarta, 1976.

John R. Bowen, Intellectual Pilgrimages and Local Norms in Fashioning Indonesian Islam, REMMM 123.

M. Dahlan M., Dinamika Perkembangan Islam Di Asia Tenggara Perspektif Histori, Jurnal Adabiyah Vol. XIII nomor 1/2013.

M.M, Syarif, Muslim Thought (trans. M. Fachruddin) Diponegoro, Bandung.

Mastuki HS, Islam, Budaya Indonesia, Dan Posisi Kajian Islam Di Perguruan Tinggi Islam, Khazanah: Vol. XII. No. 01 Januari-Juni 2014. 
Mohamad Kholil, Menggagas Pesantren sebagai Pusat Peradaban Muslim di Indonesia, Media Akademika, Vol. 26, No. 3, Juli 2011.

Moeflich Hasbullah, Century of NU-Muhammmoeflich Hasbullah, Adiyah In Indonesia: The Failure Of Islamic Modernism?, Islamika Indonesiana, 1:1 (2014).

Mujamil Qomar, Ragam Identitas Islam Di Indonesia Dari Perspektif Kawasan, Epistemé, Vol. 10, No. 2, Desember 2015.

Mugiyono, Perkembangan Pemikiran Dan Peradaban Islam Dalam Perspektif Sejarah, JIA/Juni 2013/Th.XIV/Nomor 1/1-20.

Muhammad Harfin Zuhdi, Tipologi Pemikiran Hukum Islam: Pergulatan Pemikiran Dari Tradisionalis Hingga Liberalis, Ulumuna Jurnal Studi Keislaman, Volume 16 Nomor 1 (Juni) 2012.

Mohammad Muslih, Pemikiran Islam Kontemporer, Antara Mode Pemikiran dan Model Pembacaan, Jurnal Tsaqafah, Vol. 8, No. 2, Oktober 2012.

Mun'im Sirry, Tradisi Intelektual Islam Rekonfigurasi Sumber Otoritas Agama, Madani, Malang, 2015.

Norazlan Hadi Yaacob, Muslim Intellectuals and the Idea of Madani (Civil) Society Formation in Indonesia and Malaysia, 1990s-2000s, Journal of Applied Sciences Research, 9(6): 2013.

Phikip K. Hitti, Islam A Way Of Life, Regnery/Gateway, Inc. Indiana, 1970.

(Raihani, Religious Intellectualism And Society, An Editorial Note, APJRS, Vol. 1, No. 1, March 2015.

Richard C. Martin, Islam, a cultural perspective), Prentice-Hall, Inc, New Jersey, 1982

Rusdin, Islam Dan Sastra Melayu Klasik, Jurnal Hunafa Vol. 2 No. 3 Desember 2005.

Rusydy Zakaria, Overview Of Indonesian Islamic Education A Social, Historical and Political persepective, A thesis Submitted in partial fulfillment of The requirement for the degree of Master of Philosophy at The School of Education The University of Waikato, 2007.

S. I. Poeradisastra, Sumbangan Islam Kepada Ilmu Dan Kebudayaan Modern, Girimukti Pasaka, Jakarta, 1981.

Sapardi Djoko Damono, Kesusastraan Indonesia Sebelum Kemerdekaan, Jurnal Kalam 25 / 2013.

Syed Hamid bin Syed Jaafar Albar, The Role of Islamic Civilisation in Strengthening the Foreign Relations between Countries of ASEAN, Proceedings ASEAN Community Conference 2015, Bangi, Malaysia, 1112 November 2015.

Syyed Hosein Nasr, Islam Religion, History, and Civiulization, HarperSanFransisco, New York, 2003.

Syed Muhammad Naquib al-Attas, Preliminary Statement On A General Theory Of The Islamization Of The Malay-Indonesian Archipelago, Kuala Lumpur, (1969).

Tsuroya Kiswati, Rekonstruksi Metodologis Wacana "Keadilan Gender" Dalam Prespektif Intelektual Muslim Kontemporer, Chapter Seven The Legacy of 
Islamic Thought: Contribution for the Future, Annual International Confrence On Islamic Studies.

Yudi Latif, Inteligensia Muslim dan Kuasa Genealogi Inteligensia Muslim Indonesia Abad Ke-20, Yayasan Abad Demokrasi, Jakarta, 2012. 